\title{
A Tribute to Stewart Dixon MacDonald, 1927-2010
}

\author{
DAVID R. GRAY and SALLY E. GRAY
}

Grayhound Information Services, 3107 8th Line Road, Metcalfe, Ontario K0A 2P0 Canada; e-mail: grayhound@xplornet.com

Gray, David R., and Sally E. Gray. 2012. A tribute to Stewart Dixon MacDonald, 1927-2010. Canadian Field-Naturalist 126(3): 245-251.

Stewart Dixon MacDonald wanted to be known as "Stu," specifically to be pronounced "Stoo." Not "Stew." "I don't want to share my name with a dish of meat," he said.

And there we have Stu MacDonald's easy sense of informality and gentle sense of humour, for which he was known throughout his 83 years. These endearing aspects of the arctic scientist's character were carried in a body characterized first and foremost by smiling eyes and gentle, slow speech. One might be tempted to guess the wavy-haired, bearded gentleman was simply a teddy bear, but if he was, he was of the polar variety -alert, focused, and formidable.

Born in Bayhead, Nova Scotia, in 1927, Stu became interested in the nature of the world round him at a young age. As a teen, he encountered others with shared passions and developed skills that would influence his life. After finishing high school he was hired as a technician in the Zoology section of the National Museum of Canada (now the Canadian Museum of Nature) in
Ottawa in 1947. He began his long career in the Museum cleaning bird and mammal skulls, and ended it as Curator of Vertebrate Ethology, a section he established in the early 1970 s.

Public education as a museum curator was a natural outlet for Stu's love of and delight in the natural world, particularly birds, and he was a natural teacher. He was a popular speaker, an artist, and a gifted writer, to which his bibliography attests. He also gave much heed to encouraging and training young, upcoming naturalists and scientists.

A major part of Stu's early career was the almost annual field trip to various parts of Canada. Here he utilized his skill in the preparation of bird and mammal study skins, a skill that he practised throughout his career, resulting in thousands of specimens in the Museum collections.

Stu's developing skills in collecting, preserving, and mounting birds and mammals also led to important contributions to many of the well-loved dioramas in

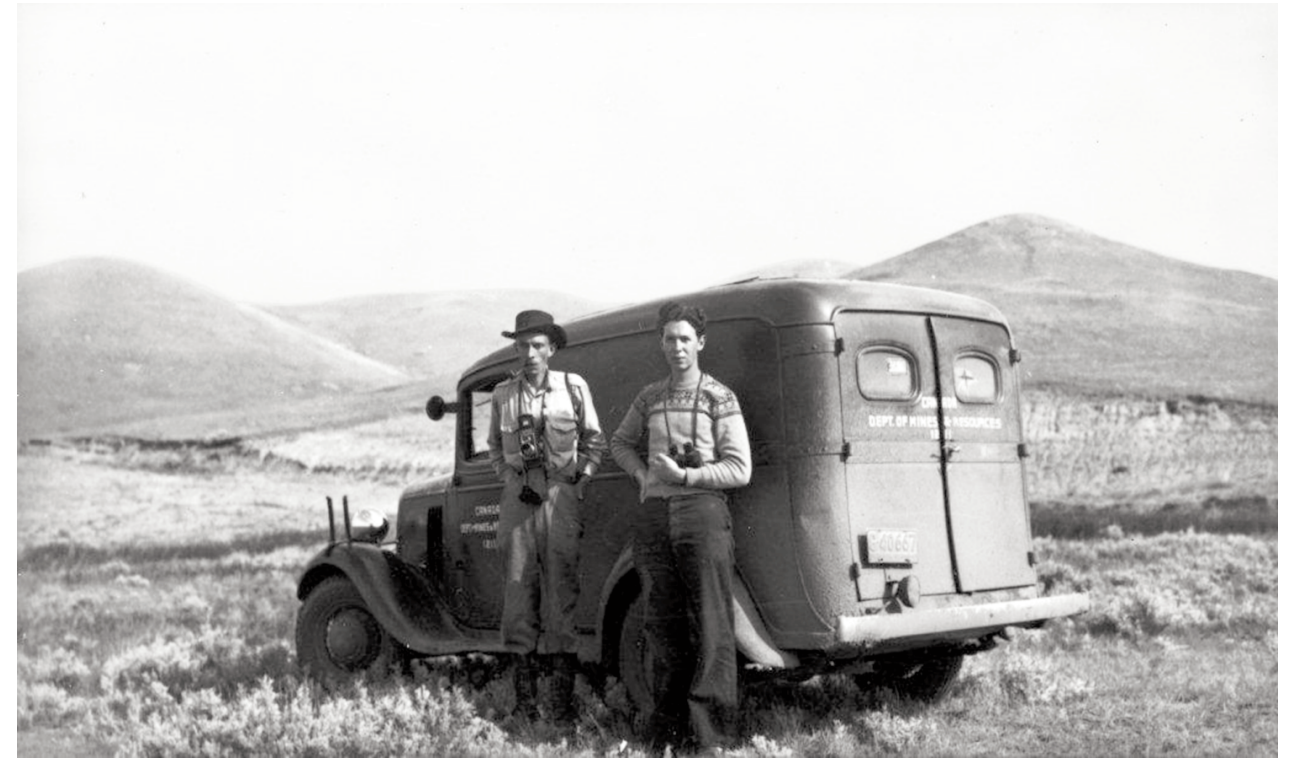

FIGURE 1. National Museum of Canada ornithological expedition to Saskatchewan, 1948. Rodger O. Standfield (left) and Stewart D. MacDonald with field vehicle, a Department of Mines and Resources truck (the Museum was part of this department at the time). Canadian Museum of Nature archives. 
the Museum's mammal and bird halls, some of which are still at the Canadian Museum of Nature today. He worked with many well-known artists at the Museum, including Clarence Tillenius and Terry Shortt. The different Museum collecting and display projects took Stu across Canada, from the Yukon mountains in the west to the Labrador Sea in the east, and from Alert on the northern tip of Ellesmere Island to Point Pelee, Canada's southernmost tip of land. However, it was the Canadian Arctic that became the dominant focus of Stu's career.

Stu's first arctic ventures were made possible by the opening of the string of weather stations in the High Arctic jointly established and staffed by the Canadian and U.S. governments just after World War II. His first expedition into the High Arctic was in 1949, when he travelled to Mould Bay on Prince Patrick Island for the National Museum of Canada in conjunction with the Smithsonian Institution. As on all of his subsequent research trips, he collected a wide range of specimens, including plants, invertebrates, fish, birds, and mammals. This introduction began a love affair with the Arctic that ended only with his death.

On his next trip to the High Arctic, in 1951, Stu spent five and a half months in the vicinity of Alert, on northern Ellesmere Island. He observed Arctic Wolves and Peary Caribou and made a series of colour photographs of all aspects of life in the Arctic. He returned to Mould Bay for the summer of 1952, again spending five months in the field. Highlights of that trip include the successful collecting of 50 lots of marine and freshwater invertebrates and a medical evacuation to Montreal for treatment of an infected seal bite! Stu's great interest in the behaviour of arctic birds continued to develop, and he made sketches of the courtship behaviours and postures of several bird species.

The third in the series of biological investigations at the weather stations in the High Arctic was conducted in the summer of 1954 at Isachsen, on Ellef Ringnes Island. Stu's notes on Rock Ptarmigan behaviour that summer were undoubtedly the springboard for the more intensive studies on Rock Ptarmigan he carried out in the late 1960s and 1970s.

In the summer of 1955, Stu headed north again, this time to the west side of Ellesmere Island, working in the vicinity of the weather station at Eureka on the Fosheim Peninsula. On this trip, he was accompanied by David F. Parmelee, who became a long-standing field partner, collaborator, and friend. This trip also saw the beginnings of an important collaboration with Fred Roots, then of the Geological Survey of Canada. With the logistical support of Fred and the Geological Survey, Stu was able to fly to and survey many points on Axel Heiberg Island and western Ellesmere Island.

Stu's published reports on those early trips to the Arctic are still a valuable source of information on many aspects of arctic biology, and they are essential reading for newcomers to arctic science and fieldwork.
Some of the northern localities Stu worked in have seldom been visited by biologists since then. The early collections of arctic flora and fauna, too, are an invaluable resource for current comparative or baseline studies. The detailed notes that Stu made on many aspects of bird and mammal behaviour during his early trips to the Arctic foreshadow the ethological studies that became the focus of his later career.

Stu resigned from his position at the National Museum in 1956 to attend the State University of Iowa. On his return to Ottawa in 1959, he became Assistant Curator of Birds under the Curator, W. Earl Godfrey. A major result of that collaboration was the publication of The Birds of Canada, first published in 1966. The information that Stu had personally gathered in the Arctic greatly improved the distribution maps of many birds whose ranges extend into the arctic regions. He also prepared many fine black-and-white illustrations for this first edition, most of which were retained in the revised edition, issued in 1986.

To Stu, with his vast experience in field studies, particularly in studying birds, it was clear that complex patterns of behaviour, such as the breeding behaviours of birds, are as characteristic of a species as any structural or morphological features. He realized that species can often be recognized as easily by their behaviour as by their structure, and he recognized the study of ethology (animal behaviour) as an important tool for taxonomists.

It was this passion for the study of ethology that led Stu to push for the establishment of a Museum section dedicated to the study of animal behaviour. This dream came into existence in 1972 with the formation of the Vertebrate Ethology section in the Vertebrate Zoology Division at the National Museum of Natural Sciences, National Museums of Canada. Stu then became the Curator of the Vertebrate Ethology section, a position he held until his retirement in 1988.

This unique section of the Museum survived for 22 years. It ended in 1994, due to reorganization and budget cuts that also eliminated scientists from some traditional museum disciplines. What has survived at the Museum is an impressive collection of still photos, moving images, and sound recordings, captured as part of the program of ethological research. Many of the sounds Stu recorded have also been archived at the Cornell Laboratory of Ornithology.

\section{The High Arctic Research Station}

While assembling data on geographic distribution for The Birds of Canada, Stu recognized a major gap in our geographical knowledge of arctic wildlife-a vast area in the Queen Elizabeth Islands known as the "barren wedge." Here the influence of the cold Arctic Ocean penetrates far to the south.

Based on his knowledge of the fauna of the arctic islands, Stu realized that Bathurst Island, which was virtually unknown biologically, would be an important 
and fascinating place to study in the "barren wedge." Bathurst Island was potentially between the ranges of eastern and western bird populations, and the number of breeding species, their migration patterns, and their taxonomic relationships would be of great interest.

Stu decided to organize an expedition to Bathurst Island, and he chose the wet lowland bisecting the island, named Polar Bear Pass, as an area that was likely to support abundant vegetation and wildlife. It was also close enough to Resolute Bay for efficient logistic support.

The first expedition to Polar Bear Pass was in the summer of 1968. Supported wholeheartedly by Fred Roots, then Director of the Polar Continental Shelf Project, Stu and two fellow scientists, with two young field assistants (one was DRG), set up a temporary research base and began a series of studies of the behaviour and ecology of arctic birds and mammals.

With several successful seasons completed, including DRG's 11-month overwinter stay at Polar Bear Pass, Stu set out to campaign for a more permanent presence there. In 1972, with the continued support of the Polar Continental Shelf Project and a grant from the Anglo-American Oil Company, the High Arctic Research Station gained a permanent building to support the growing number of researchers who worked there each season. Designed by Stu and his colleagues, the lab building featured an observation tower as well as working and sleeping space. With this new "permanent" status, Stu was appointed Director of the High Arctic Research Station.

That his choice of place and timing was an astute one is demonstrated by the 25 successive years that scientists returned to investigate all aspects of this remarkable place. As well as zoologists, botanists, climatologists, ecologists, and archeologists, Stu also encouraged artists, musicians, writers, and even politicians to visit the research station.

The list of publications-books, scientific papers, popular articles, graduate theses, and documentary films-based on research in Polar Bear Pass runs to an impressive 150 items. Among the books about the studies at Polar Bear Pass are High Arctic (1971), an account of artist George Miksch Sutton's time at the Station, Peter Buerschaper's Arctic Journey: Paintings, Sketches, and Reminiscences of a Vanishing World (1977), and The Muskoxen of Polar Bear Pass by DRG (1987), an illustrated account of the longest running project at the Station.

Although the Canadian Museum of Nature gave up the High Arctic Research Station when the Vertebrate Ethology section was closed in 1994, the lab building is still used, both by researchers and occasionally by Inuit from Resolute Bay.

\section{Stewart as Conservationist}

During the early 1970s, when oil companies proposed to build a pipeline across Polar Bear Pass, they

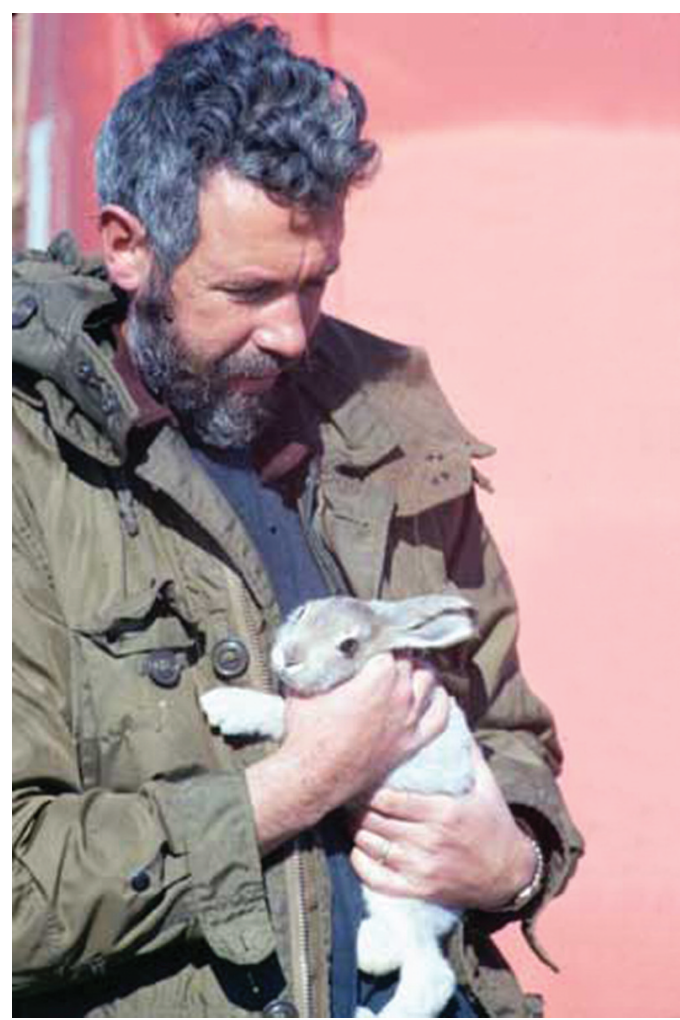

FIGURE 2. Stu MacDonald holding an Arctic Hare, 30 July 1968, at Polar Bear Pass, Bathurst Island. Photo: David R. Gray.

met formidable opposition, led by Stu. The gentle bear opened the windows of the world to the Pass with his tour of beautifully illustrated lectures, his 1976 photographic exhibit, "An Arctic Oasis," and many public media talks. It was a long 18 -year battle led by Stu, but victory was attained in 1986. Public pressure encouraged the Canadian government to create a national wildlife reserve of $2624 \mathrm{~km}^{2}$ around and including Polar Bear Pass. The Polar Bear Pass National Wildlife Area was the first of five such national wildlife areas set aside to preserve wildlife and habitat in what is now Nunavut.

It is interesting to recall that during meetings between government representatives and the oil companies, Stu's efforts to preserve the Pass were described as "jeopardizing the economic future of Canada."

A research cruise to the Antarctic in 1972, with David Parmelee, allowed Stu to expand his horizons to include the conservation of birds of the south polar regions as well.

As opportunities arose, Stu continued his surveys of breeding birds throughout the High Arctic. His discovery in 1973 of the only known colony of Ivory Gulls in Canada, on Seymour Island, off the northwest coast 
of Bathurst Island, led to a unique three-year study of this rare and endangered gull. Several years later, in 1976, he discovered what was then the only known breeding location for Ross's Gull in Canada, on the Cheyne Islands in the channel east of Bathurst Island. Again several seasons of dedicated, intensive study under incredibly difficult conditions resulted in new knowledge of another rare gull species. In the research camps on both Seymour Island and the Cheyne Islands, prowling Polar Bears challenged the observers, and at times both the bears and Arctic Foxes destroyed the breeding colony. Stu's discovery led to the establishment of the Seymour Island Migratory Bird Sanctuary in 1975 .

Based on his work to preserve the wildlife and their habitats in Polar Bear Pass and on Seymour Island, Stu was awarded the Massey Medal by the Royal Canadian Geographical Society in 1992 in recognition of his great contributions to increasing Canadians' knowledge of Canada's northern geography.

\section{Stewart as an Interpreter}

Stu preferred to write popular articles rather than scientific papers, but his contributions to arctic science are widely acknowledged in spite of this. Stu struggled over the "right" way to say things in scientific papers, and scientific analysis was not his pleasure. He was much happier as an interpreter of science. Hence many of the items in his bibliography were published in more popular nature magazines, leading to a greater readership but fewer points in the museum and science world.

Stu was always focused on the important parts of life: beauty, people, and relationships. He exemplified kindness and compassion to everyone he encountered. His experiences and contacts with Inuit-at Resolute Bay in the 1950s, at Eskimo Point (now Arviat) in the 1960s, and at Grise Fiord in the 1970s-were great examples of cultural humility and positive sharing of similar interests. Stu's colour photographs of the people of those places are an important record of the changing lifestyles in the North.

Stu's arctic research and his work on preserving Polar Bear Pass and the various research projects carried out there were the inspiration for several documentary films. Working as a scientific consultant for the CBC, especially with David Suzuki and The Nature of Things, Stu effectively transferred his knowledge of and concern for arctic wildlife and habitat to a very wide audience. The $\mathrm{CBC}$ documentary productions The Arctic Islands: A Matter of Time, Ellesmereland, The Living Arctic, and Grouse Country were very much a product of his inspiration, and his talents.

As well as the notable line drawings and distribution maps in The Birds of Canada, Stu illustrated his own papers on bird behaviour, for example, the beautiful drawings of Rock Ptarmigan in his 1970 papers on their breeding behaviour and life history. As an artist, Stu had plans and dreams of paintings he wanted to create. He left behind few finished paintings, but there were several interesting started canvasses.

It was Stu's photography that became his enduring artistic legacy. Hundreds of his photographs have been published as posters and magazine covers, have been used in exhibits, and illustrate many books and magazines. Some 10000 of his images are held in the Canadian Museum of Nature's photo collection. His still and motion photography show the results of his artistic eye for composition and his naturalist's eye for capturing significant behaviours of the animals he studied and encountered. This acute eye for detail, both as an artist and as an observer of behaviour, made him a valued and excellent judge for various wildlife art competitions, and he was a willing consultant for many wildlife artists.

\section{Stewart the Man}

For DRG, working with Stu as his "boss" for over 20 years was a wonderful experience. He was always more of a colleague and a friend than a boss, providing advice and guidance in a spirit of freedom and encouragement.

When DRG began planning for an overwinter stay at Bathurst Island as a student, there were many who focused on the difficulties and challenges, but Stu and Fred Roots, both friends of all arctic research, took the road of encouragement and followed through with the practical support and advice that typify these two arctic colleagues and veterans. During that wonderful winter, Stu insisted on a radio message once a week and faithfully communicated the contents to our families.

The many years of shared experiences in the field with Stu were a rare privilege. Camp life was full of entertaining stories of past exploits and encounters. Stu was a talented camp cook, working wonders with limited resources and always setting a high standard for service to others. Each day in any camp with Stu featured a wrap-up with reports from each person's day, highlighted by the daily "Guess what I saw today!"

One can't think about Stu without thinking about his family. He and his wife, Isobel, brought up three active sons, Iain, Bruce, and Alexander, in Ottawa and later in Dunrobin (west of Ottawa), where the couple brought new life to an enchanting old farm called Windwhistle. Many friends enjoyed their hospitality and shared Stu's love of gardening over the years.

In the mid-1970s Stu was overjoyed to be able to take two of his boys to the Arctic to assist him with his research projects. This was an important time for the family, since Stu had missed so many summers with them when they were young. The three sons all show aspects of their dad in their appearance, natures, and chosen occupations.

\section{Stewart in Retirement}

When Stu retired in 1988, we collected photos and memories of his life from hundreds of people he had 


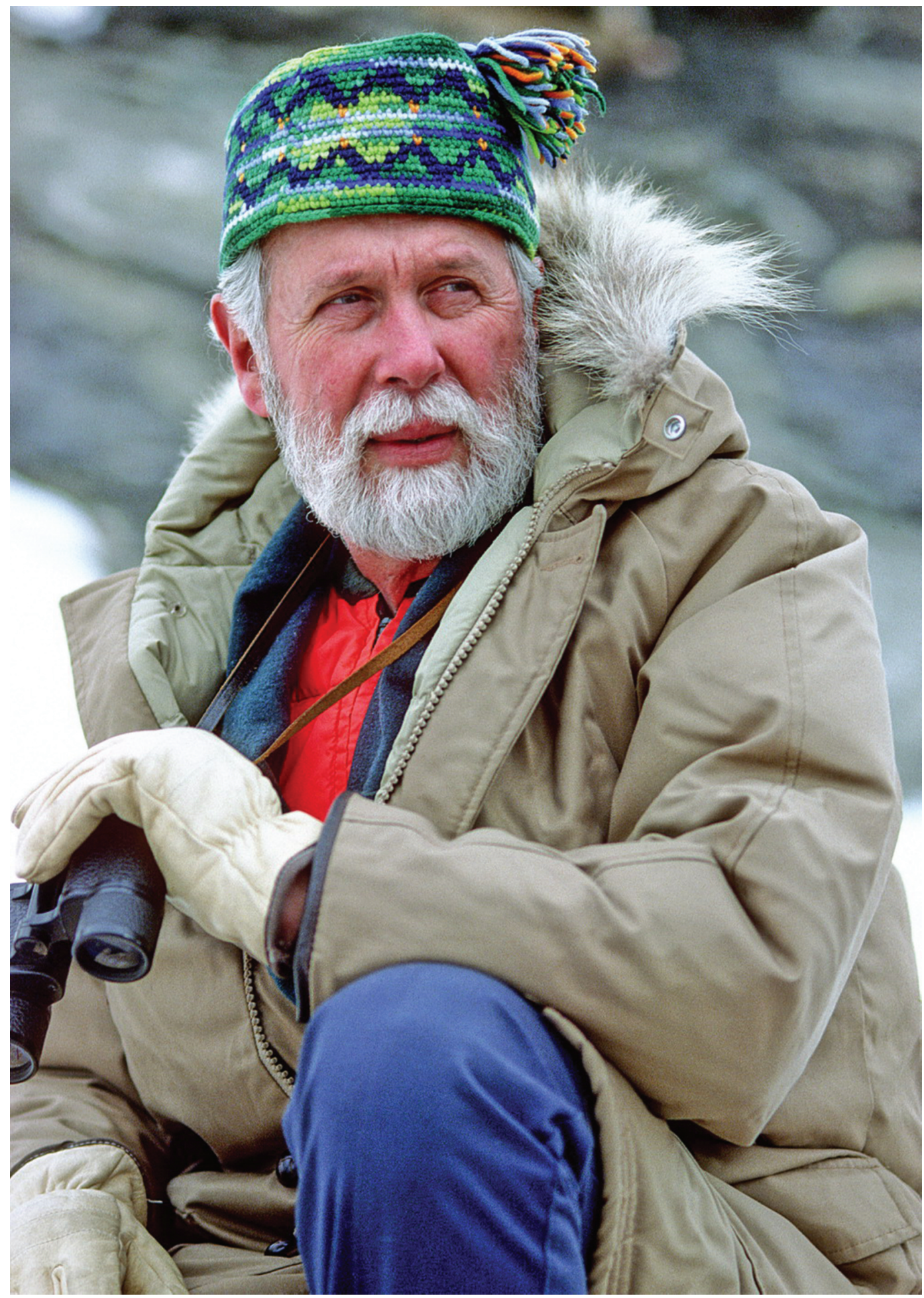

FIGURE 3. Stu MacDonald photographed near his home in Dunrobin, Ontario, March 1987. Photo: Alexander MacDonald. 
influenced in one way or another over his 40 years in the Arctic and with the Museum. The incoming mail was filled with admiring notes sent from appreciative scientists and others in many fields whose careers had been launched, or at least encouraged, by Stu.

In retirement, Stu worked with others to publish important aspects of his work on arctic gulls that he had not managed to prepare for publication while at the Museum.

In his later life, Stu also connected with a group preserving the history of the U.S.-Canada joint weather stations. Because he had worked at many of the stations in their early years, his knowledge of Alert, Mould Bay, Eureka, and Resolute Bay was unique. His contributions to the history of the early days at the weather stations were greatly valued.

Stu was predeceased by Isobel, his wonderful wife of 50 years, to whom he devoted all of his life and energy during her long illness. He delighted in his grandchildren in his retirement years. He never ran out of dreams, projects, or his love of the North, family, and friends.

When we interviewed Stu for the documentary film, Arctic Shadows, in the summer of 2009, he recalled for us, as requested, his unique memories of R. M. Anderson, former Chief Biologist at the National Museum. This was an unusual opportunity to look into the distant past of the old Museum through the eyes of one who had been there. But Stu also shared with us a review of his long and happy involvement with the Arctic, specifically the work at Bathurst Island, which obviously meant so much to him. The wonderful times shared with kindred spirits at Polar Bear Pass were clearly the high point of his arctic career.

In August 2010, when Stu had gone into the hospital for his last stay, his daughter-in-law sent an email to inform us of his situation. From an arctic expedition ship off the east coast of Baffin Island, DRG was able to tell Stu how just that week DRG had been sharing with the 75 students on the Students on Ice Expedition how much he had influenced not only DRG's own career in arctic research but also the careers of so many other young students.

Stu's impact on many young people, on the preservation of significant arctic places, and on our record of arctic wildlife, environments, and history, will continue far into the future. All of his contributions form a lasting tribute to the man described as "a scientist with the soul of an artist."

\section{Acknowledgements}

We extend our appreciation to Charles Gruchy (North Gower, Ontario), Donna Naughton (Canadian Museum of Nature), and Phillip S. Taylor (Saskatoon, Saskatchewan) for reading the manuscript and to Chantal Dussault, Andrée Bisson, Richard Martin and Susan Goods of the Canadian Museum of Nature for researching photographs, and Bruce and Alexander MacDonald for additional information on these.

\section{Bibliography of Stewart D. MacDonald}

MacDonald, S. D. 1951. Biological investigations on Prince Patrick Island. National Museum of Canada Bulletin 123: 131-132.

MacDonald, S. D. 1953. Report on biological investigations at Alert, N.W.T. National Museum of Canada Bulletin 128: 241-256.

MacDonald, S. D. 1954. Report on biological investigations at Mould Bay, Prince Patrick Island, N.W.T., in 1952. National Museum of Canada Bulletin 132: 214-238.

Parmelee, D. F., and S. D. MacDonald. 1960. The birds of west-central Ellesmere Island and adjacent areas. National Museum of Canada Bulletin 169: 1-103. 10 plates.

MacDonald, S. D. 1961. Biological investigations at Isachsen, Ellef Ringnes Island, N.W.T. National Museum of Canada Bulletin 172: 90-97.

MacDonald, S. D., and D. F. Parmelee. 1962. Feeding behaviour of the Turnstone in Arctic Canada. British Birds 55: 241-244.

MacDonald, S. D., and A. H. Macpherson. 1962. Breeding places of the Ivory Gull in Arctic Canada. National Museum of Canada Bulletin 183: 111-117.

Godfrey, W. Earl. 1966. The Birds of Canada. National Museum of Canada Bulletin 203: 1-428. Illustrations by J. A. Crosby, line drawings by S. D. MacDonald. [Issued also in French as Les oiseaux du Canada.]

MacDonald, S. D. 1968. The courtship and territorial behavior of Franklin's race of the Spruce Grouse. Living Bird 7: 5-25.

MacDonald, S. D. 1969. Preliminary report on a zoological expedition to Bathurst Island, May 18 to August 12. Arctic Circular 19: 18-20.

MacDonald, S. D. 1970. The breeding behaviour of the Rock Ptarmigan. Living Bird 9: 195-238.

MacDonald, S. D. 1970. Life history of Rock Ptarmigan on Bathurst Island, NWT. Arctic Circular 20: 44-48.

MacDonald, S. D. 1972. The Arctic: land of fragile beauty. Ontario Naturalist 11(2): 24-29.

MacDonald, S. D. 1972. Rites of spring. Audubon Magazine 74(3): 68-75.

MacDonald, S. D. 1972. Look at a marsh with straight eyes. Nature Canada 1(2): 17-19.

MacDonald, S. D. 1974. Sanctuaries of the woods. Nature Canada 3(2): 14-17.

MacDonald, S. D. 1975. Review of Paul A. Johnsgard, Grouse and Quails of North America. Canadian Field-Naturalist 89: 473-474.

MacDonald, S. D. 1975. Review of George Miksch Sutton, High Arctic-An Expedition to the Unspoiled North. Canadian Field-Naturalist 89: 485-486.

Parmelee D. F., and S. D. MacDonald. 1975. Recent observations on the birds of Isla Contramaestre and Isla Magdalena, Straits of Magellan. Condor 77: 218-220.

MacDonald, S. D. 1976. Phantoms of the polar pack ice. Audubon Magazine 78(3): 2-19.

MacDonald, S. D. 1976. Gyr! Audubon Magazine 78(4): 76-79.

MacDonald, S. D. 1977. An arctic oasis. Nature Canada 6(3): 4-6. 
MacDonald, S. D. 1977. An Arctic oasis / Une oasis arctique [exhibit]. Photography by S. D. MacDonald. National Museum of Natural Sciences, Ottawa. 12 pages. Brochure to accompany the exhibit.

MacDonald, S. D. 1979. First breeding record of Ross's Gull in Canada [abstract]. Page 16 in Proceedings: 1979 Conference of the Colonial Waterbird Group.

MacDonald, S. D. [1979?] Status report on the Ivory Gull, Pagophila eburnea, in Canada, 1978. Committee on the Status of Endangered Wildlife in Canada, Ottawa.

MacDonald, S. D. 1980. Scientific progress: terrestrial biology, an overview. Pages 171-186 in A Century of Canada's Arctic Islands 1880-1980. Royal Society of Canada.

Hollett, K. G., V. G. Thomas, and S. D. MacDonald. 1984. Structural and functional aspects of supraorbital combs of grouse. Pages 193-211 in Third International Grouse Symposium, York, England, 1984. Edited by P. Hudson and T. W. I. Lovel. International Council for Game and Wildlife Conservation and World Pheasant Association.

Godfrey, W. E. 1986. The Birds of Canada. Revised edition. National Museum of Natural Sciences, National Museums of Canada, Ottawa. Illustrations by J. A. Crosby; line drawings by J. A. Crosby and S. D. MacDonald. 595 pages. [Issued also in French as Les oiseaux du Canada, édition revisée].

Thomas, V. G., and S. D. MacDonald. 1987. The significance of terrestrial and marine oases in the High Arctic. Pages 147-153 in Arctic Heritage: Proceedings of a Symposium, August 24-28, 1985, Banff, Alberta, Canada. Edited by G. Nelson, R. Needham, and L. Norton. Association of Canadian Universities for Northern Studies, Ottawa. 653 pages.
Thomas, V. G., and S. D. MacDonald. 1987. The breeding distribution and current population status of the Ivory Gull in Canada. Arctic 40: 211-218.

MacDonald, S. D. 1990. The whelping patch: adrift on pack ice in the Labrador Sea, hooded seals give birth to their young. Nature Canada 19(3): 23-27.

MacDonald, S. D. [1990?]. Status report on the Ivory Gull, Pagophila eburnea, in Canada. Committee on the Status of Endangered Wildlife in Canada, Ottawa.

Haney, J. C., and S. D. MacDonald. 1995. Ivory Gull (Pagophila eburnea). No. 175 in The Birds of North America. Edited by A. Poole and F. Gill. Academy of Natural Sciences, Philadelphia, and the American Ornithologists' Union, Washington, D.C. 24 pages.

Alvo, Robert, and S. D. MacDonald. 1996. Updated status report on the Ivory Gull, Pagophila eburnea, in Canada. Committee on the Status of Endangered Wildlife in Canada, Ottawa.

O'Briain, Michéal, Austin Reed, and S. D. Macdonald. 1998. Breeding, moulting, and site fidelity of Brant (Branta bernicla) on Bathurst and Seymour islands in the Canadian Arctic. Arctic 51: 350-360.

Mallory, Mark L., Iain J. Stenhouse, Grant Gilchrist, Gregory Robertson, J. Christopher Haney, and S. D. MacDonald. 2008. Ivory Gull (Pagophila eburnea). No. 175 in The Birds of North America. Edited by A. Poole. The Birds of North America Online. Cornell Lab of Ornithology, Ithaca, New York http://bna.birds.cornell.edu /bna/species/175doi:10.2173/bna.175.

Received 9 March 2012

Accepted 18 September 2012 